\title{
LTB4R wt Allele
}

National Cancer Institute

\section{Source}

National Cancer Institute. LTB4R wt Allele. NCI Thesaurus. Code C51468.

Human LTB4R wild-type allele is located within $14 q 11.2-q 12$ and is approximately $4 \mathrm{~kb}$ in length. This allele, which encodes leukotriene B4 receptor 1 protein, plays a role in the regulation of the inflammatory system and is involved in the regulation of cardiac muscle contraction. 